\title{
5. Metaphors in The Wealth of Nations
}

\section{Sergio Cremaschi*}

I intend to highlight the shaping of Adam Smith's discourse on the growth of wealth, the interactions between economic theory, moral theory and the theory of knowledge, and the ways in which theory and rhetoric safely coexist in his work. ${ }^{1}$

My main claim is that, either by chance or by insight, Adam Smith worked with a blissful combination of metaphors, a combination that helped in widening the scope of economic theory, imagining counter-intuitive connections among separated fields, and shaping new hypotheses to be tested. Adam Smith's felicitous choice of his own bunch of metaphors depended on a number of factors: fashion, shared standards of taste, a received set of images and symbols, in a word, a 'scientific style'.2

\section{SCIENCE AND ANALOGY IN THE HISTORY OF ASTRONOMY}

Adam Smith left unpublished fragments of a 'philosophical history of the sciences and the arts'. Schumpeter once wrote that nobody 'can have an adequate idea of Smith's intellectual stature who does not know these essays', ${ }^{3}$ but in fact he made hardly any use of them in his own reading of The Wealth of Nations. The editors of the Glasgow edition of Adam Smith's works have done a lot to redress the effects of Schumpeter's inadvertence, but some work still is waiting to be done.

Of these fragments the most renowned one is The History of Astronomy, whose first three sections present Adam Smith's views in matters of methodology and epistemology, those views he apparently assumed to be of scarce interest to the reader of The Wealth of Nations. Adam Smith puts Hume's philosophy of mind to work as the basis of an historical reconstruction of the leading branch of natural science. Like in Hume's epistemology, the Newtonian principle of 'analogy of nature' plays a main function. This is a key principle in the Newtonian methodological tradition stating that we may safely assume that Nature is simple, and accordingly may assumed to employ similar causes in order to bring about similar effects in different domains. The adoption of such a principle, combined with Hume's view of knowledge in terms of association of ideas, yields an original account of theory change. That is, the evolution of 'systems' (i.e. theories) which account for the heavenly phenomena is governed by psychological laws. These laws prescribe that gaps in the familiar course of impressions to which our imagination has become accustomed be filled. In order to fill the gap, the mind may have recourse to imaginary ideas. Thus, the mind fills the gaps by means of 'invisible chains' or 
'imaginary machines' made of ideas. A good imaginary machine in turn is one that would bring about the observed phenomena in a simple and familiar way. ${ }^{4}$

Every time we say that a new field of (previously disconnected) phenomena has been explained, or that a better explanation has been offered for the same field, this may imply that a new 'imaginary machine' has been built, that is, the gaps between disconnected phenomena have been filled by an 'invisible' chain of phenomena, taken from some more familiar field, that are imagined to lay behind the observable phenomena. In other words, an imaginary machine is built by taking another, more familiar, field as a 'model' for the explanandum, and mapping the chosen model over the explanandum. The chain of models thus gradually produced should eventually end up with some domain where the principles at work are 'visible', not just imagined or hidden behind the veil of phenomena. Technology is the best example of such a domain, since in building tools and machines knowing is doing. ${ }^{5}$ This is why we see the various fields of natural phenomena as if they were machines.

If we assume that Adam Smith believed that this holds also for social phenomena, we may also account in a more convincing way for Adam Smith's intentions and for what he actually did also in the field of the social sciences. He probably felt that his audience was interested primarily in the moral and political implications of his argument on the causes of the wealth and poverty of nations, and this is why in The Wealth of Nations he was careful in avoiding such academic issues as methodology.

A remark may be added on analogy and metaphor. Adam Smith believes analogy to be - along with simplicity and familiarity - one of the characteristics required by the human mind to accept new imaginary ideas as parts of the invisible chain between disconnected phenomena. Analogy is always a requirement, even if there may be an excess in its use ${ }^{6}$. Metaphor, on the contrary, is but one figure of speech, and it may be used with some positive aesthetic effect, if it is used with due respect to proportions. 'In every metaphor it is evident there must be an allusion betwixt one object and an other' (Smith 1983, i.64, p. 29), but only if such an allusion consists in a resemblance it is a metaphor in a proper sense; if the allusion depends on a close connection, it is a kind of 'metonymy'. A metaphor is thus an 'alteration of the word [...] in its signification' (Smith 1983, i.63, p. 28) and consists in giving the word a meaning 'to which it has some resemblance or analogy' (Ib.). Besides, also Adam Smith believes, with the whole tradition of rhetoric stemming from Aristotle, that metaphor is one figure of speech that carries many dangers. Besides, he shares the suspicion widespread among modern philosophers (starting with Roger Bacon and the Royal Society) that only 'when the sentiment of the speaker is expressed in a neat, clear, plain and clever manner' (Smith 1983, i.v.56, p. 29) language is used as a proper vehicle for ideas and that figures of speech 'have no intrinsic worth of their own'7. This concern with clarity and literality may make the actual use of metaphors by Adam Smith - not in poetry of novel, but in philosophical and economic writings - a tricky subject of study. It is true that Smith's texts - as Vivienne Brown notes - in spite of his own precepts in the Lectures on Rhetoric, are 'at times deeply metaphorical ${ }^{8}$, but I believe that the most important aspect of Adam Smith's metaphors are their below-thewater-line parts, i.e. not the use Smith's makes of metaphors but the effects he produces on received concepts and theories by making use of metaphoric transfer of meanings from one domain to another. In other words, 
not the illocutionary dimension (the effects the author produces by the utterance itself, be they intended or not $)^{9}$ but the perlocutionary dimension, i.e. effects the author produces by the speech act as such is the decisive part of the story I intend to tell; the latter effects are always beyond control by the author, since the speech act is always in the framework of a conversation. ${ }^{10}$

\section{PHYSICAL, BIOLOGICAL AND THEOLOGICAL METAPHORS IN THE WEALTH OF NATIONS}

Unlike Malthus and, after him, other writers on economic subjects, Adam Smith did not prefix a methodological introduction to his main economic work. Indeed, a reader might look in vain for methodological comments of any kind throughout the five books of the work. Even worse, to our disappointment, speculations about first causes and original qualities lying at the root of 'principles' of economic behaviour such as the propensity to truck and barter and the propensity to exchange that occur in a number of passages of the Lectures on Jurisprudence have been systematically deleted from the text of The Wealth of Nations. Smith more than once writes at these points: we do not need to ascertain whether the above principle is an original quality of human nature or it may be reduced to some more basic quality; for our present concern we may take the above principle for granted. ${ }^{11}$ And yet, Adam Smith was dramatically aware that even Newton's work, the most splendid achievement of human reason, amounted to nothing more than an ingenious creation of human imagination, which might be reduced to analogical transfer of ideas from one domain to another. How far this dramatic awareness reflected also on his work? That is, how far was he aware that also any discovery of truths, not only in the field of nature but also in the parallel field of man and society, e.g. the reconstruction of market mechanisms, amounted to a construction of imaginary machines?

Answers to this question range from the eighteenth century view of Smith as a dogmatic social theorist, a proponent of the harmony-of-interests thesis and of an optimistic social theodicy ${ }^{12}$, to a postmodernist reading of Adam Smith as staging rhetorical devices with a view at producing persuasion in his own audience. I feel that full sense can be made of what Smith says only if we take a third way. My own answer, not surprisingly, lies somewhere in between. In order to substantiate it, I shall tell the eventful story of several families of metaphors crowding the pages of The Wealth of Nations. Let us start with a family enjoying the highest reputation in the eighteenth century: physical metaphors.

\section{Mechanics}

Besides the occurrence of the idea of gravitation, that could hardly escape the reader's attention, the presence of several physical metaphors in The Wealth of Nations has gone generally unnoticed ${ }^{13}$. But the metaphors are there and may be grouped easily according to their primary subjects. Two groups are based on mechanical subjects: the first is fall and rise, the second is circulation. 
Concerning the subject of fall and rise, the first remark worth making is that economic magnitudes appear to be located in a two-dimensional space, with a vertical as well as a horizontal dimension. Accordingly, prices and profits may move downward or upward. Smith writes:

the market price will <rise> more or less <above> the natural price (Smith [1776] 1976, I.vii.9, p. 73-74). ${ }^{14}$

The market price will <sink> more or less <below> the natural price (Smith [1776] 1976, I.vii.10, p. 74).

the <fall> of profit in them and the <rise> of it in all others immediately dispose them to alter this faulty distribution (Smith [1776] 1976, IV.vii.c.88, p. 630).

These example of ways of representing changes in economic magnitudes by mapping these changes over a two-dimensional space carry the implication that change in the economy 'is' spatial movement. This implication opens the door to several questions, namely: if there are 'motions' of prices, profits, and rents, what are the causes for such motions? Are they just efficient causes or also final causes? What kind of laws, if any, governs these motions?

The primary subject of mechanical metaphors, besides upward or downward movements, is provided on a few occasions by circular movement. Smith writes that money is the 'great $<$ wheel $>$ of $<$ circulation $>$ ' (Smith [1776] 1976, II.ii.14, p. 289; II.ii.23, p. 291), that is, its function is that of smoothing the shift of other goods from one owner to another. In this passage, 'circulation' is a rotating movement of a wheel; in other passages instead, it is the flow of a fluid, namely value, through the vessels of a living body. I will discuss these hydraulic or biological metaphors in what follows.

\section{Dynamics}

Other physical metaphors draw their primary subject from what is now another sub-discipline of physics, namely dynamics. Here not only spatial movements are at stake, but also their causes, i.e. forces.

The occurrence of the idea of gravitation is familiar even to the reader of the bunch of standard quotations from The Wealth of Nations that use to appear in economics textbooks. Smith describes prices, natural rates of salaries, profits, rents as gravitating around some average or central point that may be called a natural price. 'Gravitating' means moving upwards and downwards, but with a tendency to come back towards some given point, as if this point was able to exert some kind of attraction. Smith here spells out the metaphor by an 'as if' clause. He writes that the natural price

is, as it were, the <central> price, to which the prices of all commodities are continually <gravitating>. Different accidents may sometimes keep them <suspended> a good deal <above> it, and sometimes force them down even somewhat <below> it. But whatever may be the obstacles which hinder them from settling in this centre of <repose> and continuance, they are constantly <tending> towards it (Smith [1776] 1976, I.vii.15, p. 75) 
Also, the most famous (and often misquoted) passage from The Wealth of Nations is a metaphor based on a dynamic subject. In more detail, it is based on the Newtonian way of equating a vis a tergo (i.e. an impressed force, transmitted by direct contact between bodies) with a vis attractiva (i.e. an attractive force, by one body which carries out an 'action at a distance' on another body). In this notorious passage Smith writes:

Every individual is continually exerting himself to find out the most advantageous employment for whatever capital he can command [...] and he is [...] <led> by an invisible hand to promote an end which was no part of his intention (Smith [1776] 1976, IV.ii.4-9, p. 456).

The passage is meant to illustrate how (in present-day jargon) market mechanisms bring about optimal allocation of capitals. The passage has been quoted numberless times as an illustration of the harmony-ofinterests thesis, or as a proof of Smith's 'modernity' in forerunning the self-regulating mechanisms of postmarginalist microeconomics. In fact, what the passage tries to proof is that human actions can bring about the same effect, both in case the effect was intended and in case it was no part of the agent's intention. ${ }^{15}$ In other words, Smith's claim is not that of a deterministic character of the cause-effect relationship but instead the equivalence of a final and an efficient cause or of a vis a tergo and a vis attractiva. No suggestion is made that the hand's invisibility implies its being the Hand of God, as was safely assumed by interpreters who used to read Adam Smith as the proponent of a dogmatically optimistic social theodicy centred on the harmony-ofinterests thesis.

\section{Hydraulics}

At a number of places in The Wealth of Nations circulation is the circular flow of a fluid instead of the rotating motion of a wheel. In fact in everyday language, at least in most modern languages, cash is 'liquid', which implies that money is 'a fluid'. This is an entrenched way of speaking of money on which Smith elaborates, spelling out the further implication that the laws of hydraulics that apply to fluids, do apply to money as well. For example, while discussing one ruinous experiment in banking, he suggests that the

coffers of the bank $[\ldots]$ resemble a water pond, from which, though a stream is continually running out, yet another is continually running in, fully equal to that which runs out; so that $[\ldots]$ the pond keeps always equally, or very near equally full (Smith [1776] 1976, II.ii.59, p. 304).

Thus, the

project of replenishing their coffers in this manner may be compared to that of a man who had a water-pond from which a stream was continually running out, and into which no stream was continually running, but who proposed to keep it always equally full by employing a number of people to go continually with buckets to a well at some miles distance in order to bring water to replenish it (Smith [1776] 1976, II.ii.76, p. 316). 
A similar primary subject, drawn from hydraulics, provides the basis for another metaphor, invoked in order to account for the devastating effects of accumulation of gold and silver in Spain and Portugal after the conquest of South America. Smith writes:

When you dam up a stream of water, as soon as the dam is full, as much water must run over the dam-head as if there was no dam at all $[\ldots]$ As the water, however, must always be deeper behind the dam-head than before it, so the quantity of gold and silver which these restraints detain in Spain and Portugal must, in proportion to the annual produce of their land and labour, be greater than what is to be found in other countries (Smith [1776] 1976, IV.v.a.19, p. 512).

\section{Biology and medicine}

Almost inadvertently, as soon as blood is substituted to water, the primary subjects of metaphors shift from hydraulics to biology and medicine. Here is Harvey's discovery of the circulation of blood that provides the blueprint. Smith writes that the monopoly of the colony trade seems to have modified the 'natural balance' among different branches of the British economy and

Commerce, instead of running in a great number of $\langle$ small channels $>$, has been taught to run principally in one <great channel> (Smith [1776] 1976, IV.vii.c.43, p. 604).

As a consequence, the 'whole system of her industry and commerce' has become less safe. This has made

the whole state of her < body politick> less healthful, than it otherwise would have been [...] one of those unwholesome bodies in which some of the vital parts are overgrown [...] A small stop in that great bloodvessel, which has been artificially swelled beyond its natural dimensions, and through which an unnatural proportion of the industry and commerce of the country has been forced to circulate, is very likely to bring on the most dangerous disorders upon the whole body politick (Smith [1776] 1976, IV.vii.c.43, pp. 604-605).

And he concludes that the blood,

of which the circulation is stopt in some of the smaller vessels, easily disgorges itself into the greater, without occasioning any dangerous disorder; but, when it is stopt in any of the greater vessels, convulsion, apoplexy, or death, are the immediate and unavoidable consequences (Smith [1776] 1976, IV.vii.c.43, p. 605).

The latter quotation states that society is an organism, or a body. The quote embodies a mixed metaphor which maps the secondary subject over two primary subjects at once. In fact, at a certain level, commerce is the flow of a liquid; at a further level, this liquid is what nourishes a living organism. The idea of society as an 
organism is another entrenched image, lying at the root of the classical phrase "the body politick". Some political theorizing has been done starting with classical authors by elaborating on this idea. In The Wealth of Nations, the idea comes back more than once. For example, the effort of every man 'of bettering his own condition' is, for society as a whole, a 'principle' that keeps it healthy. We find here once more an explicit simile:

This $[\ldots]$ effort of every man $[\ldots][1]$ ike the unknown <principle of animal life> [...] frequently restores health $[\ldots]$ in spite, not only of the disease, but of the absurd prescriptions of the doctor (Smith [1776] 1976, I.iii.31, p. 343).

And Smith further elaborates on this point while discussing the doctrines of the Physiocrats. The focus of his criticism is the kind of artificialism that lies at the root of Physiocracy. He notes that some 'speculative physician seem to have imagined that the health of the human body could be preserved only by a certain precise regimen of diet and exercise'. He seems to be alluding in fact to a famous Scottish physician of his time, Nicholas Cheyne, who was the proponent of a Christian Stoic view, recommending an ascetic regime (See Cheyne, 1725). Smith's remark is that experience, on the contrary 'would seem to show that the human body frequently preserves, to all appearance at least, the most perfect state of health under a vast variety of different regimens' (Smith [1776] 1976, IV.ix.28, p. 673), and that

the healthful state of the human body [...] contains in itself some unknown principle of preservation, capable of preventing or correcting, in many respects, the bad effects even of a very faulty regimen. Mr. Quesnai, who was himself a physician [...] seems to have entertained a notion of the same kind concerning the <political body $>$ [...] In the political body, however, the wisdom of nature has fortunately made ample provision for remedying many of the bad effects of the folly and injustice of man; in the same manner as it has done in the natural body (Smith [1776] 1976, IV.ix.28, p. 673674; emphasis added).

The reader may note that the 'principle of preservation' lies at a level deeper than that of observable phenomena. It may be not unreasonable to think that it is the same non observable level of 'invisible' chains, 'invisible hands' and 'imaginary' machines, and that the dual structure of observable phenomena and hidden connecting principles may be assumed to exist not only in nature, but also in society. In the latter case the hidden level includes behaviour of individuals in their private lives, i.e., phenomena that are apparently unconnected to each other. Also in social phenomena 'philosophy' proves to be able to bring about connectedness. In fact, 'the natural effort which every man is continuously making to better his own condition' (Ib.) plays in the body politick the same role as the 'unknown' principle of preservation plays in the biological body $^{16}$.

\section{Agriculture, or energy}


Another sustained metaphor, or an allegory, may be detected in Book II, where value is described as a substance, something like a force transformed into energy. Smith says that 'the labour of the manufacturer <fixes> and realizes itself in some particular subject or vendible commodity [...] It is, as it were, a certain quantity of labour stocked and stored up' (Smith [1776] 1976, II.iii.1, p. 330). This quantity of labour stored in some portion of matter 'can afterwards [...] put into motion a quantity of labour equal to that which had originally produced it' (Ib.). What Smith seems to have in mind is a transformation of labour (active force) into value (energy) stored in land (matter).

It is this hidden fluid or substance what keeps the economy alive, and this 'abstract' entity survives to the transformation or consumption of material goods. In fact

what is annually saved is as regularly consumed as what is annually spent $[\ldots]$ but it is consumed by a different kind of people [...] That portion which he annually saves, as... it is immediately employed as a capital, is consumed [...] by labourers [...] who reproduce with a profit the value of their annual consumption (Smith [1776] 1976, II.iii.18, p. 338).

Trying to sum up what is suggested by a review of the various families of metaphors, we could read into The Wealth of Nations some kind of allegory. This allegory represents the economy as a rotating wheel or a circulating fluid, following blueprints drawn from astronomy, biology and agriculture. Such a circular process is understood as a self-expanding process, since, as soon as a new cycle begins, fresh portions of land and labour are 'attracted' into the economy's circular movement.

\section{METAPHORS IN THE THEORY OF MORAL SENTIMENTS AND THE ESSAYS ON PHILOSOPHICAL SUBJECTS}

The most famous passage from Smith, that is the invisible-hand passage, actually occurs twice: the first time in The Theory of Moral Sentiments in connection with consumption and distribution, the second in The Wealth of Nations, with reference to investment. But other hands, more or less invisible, occur at other places in Smith's oeuvre.

An 'invisible hand' had already shown up in the 'History of Astronomy'. After noting that the worldpicture of ancient peoples used to ascribe to divine intervention only irregular events, not ordinary ones, he adds: 'Fire burns, and water refreshes; heavy bodies descend, and lighter substances fly upwards, by the necessity of their own nature; nor was the invisible Hand of Jupiter ever apprehended to be employed in those matters' (Smith [1795a] 1980, III.2, p. 49). ${ }^{17}$ 'Of the External Senses' talks, instead of God's hand, of the hand of Nature. Smith writes that 'Alarm is always the fear of some uncertain evil beyond what is immediately felt, and from some unknown and external cause' (Smith [1795b] 1980, 87, p. 168). It is an effect produced so quickly that it may seem 'an impression immediately struck by the Hand of Nature' (Ib.). 
In The Theory of Moral Sentiments hands are mentioned twice. The first time, within the context of a discussion on the significance of wealth for human happiness, Smith suggests that the rich contribute, through an unintended effect, to the livelihood of their fellows. The rich

consume little more than the poor, and [...] by the gratification of their vain and insatiable desires, they divide with the poor the produce of all their improvements. They are <led by an invisible hand > to make nearly the same distribution of the necessaries of life, which would have been made, had the earth been divided into equal portions among all its inhabitants (Smith [1759] 1976, IV.1.10, p. 184).

The passage from The Wealth of Nations on the invisible hand and optimal allocation of capital has often been matched with this, but not with another page in The Theory of Moral Sentiments where Smith mentions chessboards. Smith says that the "man of system", that is, the doctrinaire political reformer

seems to imagine that he can arrange the different members of a great society with as much ease as the hand arranges the different pieces upon a chessboard. He does not consider that the piece upon the chessboard has no other < principle of motion> of its own, altogether different from that which the legislature might chose to <impress> upon it (Smith [1759] 1976, VI.ii.2.17, p. 234).

The quoted passage (from the 1790 additions) is meant to stress the distinction between human intentions and unintended results. The implications are that individuals in society are like bodies provided with an original motion, previous to any 'artificial' intervention. One obvious consequence is that political artificialism is ineffective, since it ignores the 'dynamic' dimension of social life. A less obvious precondition of what Smith says is a picture of society that depicts it not as a machine but instead as a system that is never at rest. The source of this picture may be Hobbes' atomistic view of nature, consisting of parts endowed with an original principle of motion or, in the jargon of seventeenth-century natural philosophy, with a conatus. It may be also a closer source, namely the Newtonian view of the universe, where the planets are never at rest, and yet a state of equilibrium is produced by the principle of gravitation.

To sum up, metaphors are no less frequent in The Wealth of Nations than in other works by Smith with a more traditionally 'literary' character; indeed, the favoured primary subjects of metaphors appear to be the same in all of Smith's oeuvre. Only the theme of circulation is probably peculiar to The Wealth of Nations. When seen from this viewpoint, Adam Smith's discourse tends to sound much in the same voice in both The Wealth of Nations and The Theory of Moral Sentiments ${ }^{18}$ 


\section{SOURCES OF ADAM SMITH'S METAPHORS}

Adam Smith's metaphors tend to be mixed metaphors, a kind of metaphor that never met with success among literary critics. And his way of building economic theories tends - pace the anti-baroque leanings of the 'Augustan Age' and his own stylistic precepts in the Lectures on Rhetoric - to yield allegories (i.e., stories told by sustained use of a few metaphors). In fact, the sources from which he draws either primary subjects or metaphors to be further developed are at once previous economic doctrines, moral and political philosophy natural philosophy, biology, medicine, and agriculture. Besides, several of these themes are mapped onto each other, or the implications of one metaphor are further developed taking advantage of developments in the primary subjects. Examples thereof are Harvey's theory of sanguine circulation for the iatro-mechanical analogy or Newton's idea of gravitation for the pre-existing analogy of the social order and a state of equilibrium in a pair of scales. Thus, the themes of society as an organism, money or value as fluids, labour as a force embodied into matter, circulation, passions as forces, individuals as atoms, society as a machine, gravitation and invisible hands coexist with each other and are occasionally blended together.

Let us look at several sources of the metaphors that have been reviewed above. One source is moral and political discourse. From this context derives the view of society as a kind of a cosmos. This view was widespread among Renaissance writers, combined with a Platonic assumption of a correspondence between microcosm and macrocosm. It won different implication as soon as the connotation of the primary subject (i.e., the physical universe) underwent gradual modifications. The view of society as analogous to the Newtonian universe presented by English Platonic rationalists such as Ralph Cudworth and Samuel Clarke opened the way to a transfer of concepts of force and equilibrium from the physical to the social realm. Human passions were understood as forces causing social motion, and the rational order that is produced as a result of the combined effects of those passions - the non-rational behaviour of individuals notwithstanding - is equivalent to the equilibrium of the 'isolated system' of post-Galilean physics.

Another source is provided by previous economic theories, particularly those of economic pamphleteers of the seventeenth and eighteenth centuries. This provides a number of tentative analogies on which Smith elaborates. The economic pamphleteers of the XVII and XVIII centuries repeated several times a few basic mechanical analogies. Hume, in 'Of the Balance of Trade' (1758a, p. 333) mentions the dam and the stream in order to stress the same point made by Smith in The Wealth of Nations. In 'Of Money' he mentions wheels with reference to money but, curiously enough, he seems to think of trade not in terms of circulation, but of a machine run by wheels. In this connection he also talks of money in terms of oil which reduces friction. He writes:

Money is not, properly speaking, one of the subjects of commerce... It is none of the wheels of trade: It is the oil which renders the motion of the wheels more smooth and easy (Hume, 1758b, p. 309).

Cantillon, in the Essai sur la nature du commerce en général (1755, I.x) talks of 'perpetual ebbs and flow' of market prices $^{19}$. 
Sources of Smith's circular view of the economy (besides the all-pervading Stoic cyclical view of both history and nature) are the economic pamphleteers, such as Thomas Mun and Edward Misselden, and the Physiocrats. $^{20}$

One notorious source of Smith's views on value is Locke's theory of property, justified on the ground of the intercourse between man and land. Labour, according to Locke, 'makes the far greatest part of the value of things, we enjoy in this world' (Locke [1690] 1988, par. 42, pp. 297). Since the labour of his body and the work of his hands are his property, what has been removed 'out of the State that Nature hath provided', he 'hath mixed his Labour with, and joyned to it something that is his own, and thereby makes it his Property' (Locke [1690] 1988, 27, pp. 287-288). Locke's labour is apparently a creative activity, while matter is a passive res extensa. Thus, the former may be seen as a force which becomes energy when it is infused into matter. Such a vision may suggest one further implication, that actually takes place in Smith, i.e., the idea that value, as 'labour embodied', is a force or energy incorporated into material things.

Another notorious source of metaphors - and an occasion of heavy misunderstanding of Adam Smith's discourse - is post-Reformation theology. A contemporary example of use of the notion of the hand of God is in Priestley; he writes that the study of history 'strengthens the sentiments of virtue by the variety of views in which it exhibits the conduct of Divine Providence and points out the Hand of God in the affairs of men' (Priestley [1788] 1970, p. 25). ${ }^{21}$

Biology, medicine, and agriculture are another family of sources. The most important theme from these sources is the idea of circular processes. Circulation started to be a fashionable idea since Harvey discovered the circulation of blood in the human body. Quesnay was himself a physician, and he looked at a familiar phenomenon, namely the 'circulation' of corn, from seed to crop, and back, through Harvey's lenses: thus corn became a fluid running though the body of society and bringing life to it; society itself was an organism, like a tree, and a fluid running through its trunk and branches used to bring nourishment, first produced by agriculture, to industry and commerce ${ }^{22}$.

Note that, once again, the older iatro-political simile was revived thanks to a re-description of the primary subject (i.e. society is a body; but bodies live thanks to blood circulation; therefore, also societies have some 'circulation' of some kind of 'blood'). Thus, an already blurred source for one of Smith's mixed metaphors is the Physiocrats' view of the reproduction of wealth, understood in terms of agricultural cycles where seed is laid down into land, and comes back again, as crop, at the starting-point of a new cycle. One implication of the Physiocrats' circular view of the process of reproduction of wealth is the view of wealth as a 'substance'23. For the Physiocrats, that substance was corn, which could be used as the seed for new wealth. In Smith, this same scheme is preserved, but substituting labour-value for agricultural produce.

Let us come to the source of the main family of metaphors namely physics. From this source Smith draws his idea of 'equilibrium' (Note that there is no such word in Smith). Smith's idea of 'equilibrium' is derived, through contamination, both by the gravitation of the Newtonian cosmos and by the scales, the body politic analogy typical of 'liberal' political thinking of the 17 th and 18 th centuries ${ }^{24}$.

Besides, Newtonian mass and Smithian value are twin concepts. An equivalent of the first definition of 
Newton's Principia can be traced in The Wealth of Nations, according to which quantity of matter, or mass, is in proportion to weight, resulting from density and bulk jointly. The Wealth of Nations may be assumed to give the following definition: goods are endowed with an intrinsic property, value. Value - given a stable monetary unit - is in proportion to monetary price; value per unit of commodity corresponds to the Newtonian density; product, measured in physical terms, corresponds to bulk ${ }^{25}$.

The idea of the invisible hand in The Wealth of Nations is one more item, together with gravitation, of the system of forces that keeps the economy as a whole in a state of balance, or spontaneously restores this state once it has been altered. In other words, the invisible hand belongs to the context of the physical-political analogy, not to that of the theological-political analogy. A digression on the occurrence of the expression 'invisible hand' in the correspondence between Newton and his disciple and editor Cotes is in order here.

\section{INVISIBLE HANDS IN NEWTON}

The notorious expression 'invisible hand' occurs, half a century before The Wealth of Nations, in a letter from Roger Cotes to Newton. The former raises an objection to Newton with regard to gravitation; he argues that attraction of one planet by another, caused by a non-observable principle such as an attractive force, would look to the observer as the effect would look of an 'invisible' (that is, invisible to an observer under a given perspective) hand which would push a sphere laid on a table towards another sphere. In other words, the wording is used by Cotes to point to example of a non-observable cause for an observable motion.

Suppose two globes A \& B placed at a distance from each other upon a table, \& that whilst A remains at rest B is moved towards it by an Invisible Hand. A by-stander who observes this motion but not the cause of it, will say that B does certainly tend to the centre of A, \& thereupon he may call the force of the invisible Hand the centripetal force of B, or the attraction of A since ye effect appears the same as if it did truly proceed from a proper \& real attraction of A (R. Cotes, 1712/1713, p. 392).

Cotes's invisible hand is not the hand of a God who impresses motion on planets or who intervenes in order to repair breakdowns in the great clock of the universe. Cotes's invisible hand is just a human hand pushing a globe placed upon a table while being hidden to an observer who is looking at the globe from a certain perspective. What is important for Cotes is the eventuality of an unobserved cause for an observed motion. He intends to stress the possibility of accounting for one phenomenon in two alternative ways.

Cotes's use of such an expression is important for us, even if it is unlikely that Smith may have been acquainted with his correspondence with Newton. There might have been some other shared source that I have been unable to detect, or there may have been some kind of oral tradition. In any event, in Cotes's letter the invisible-hand simile was introduced to express the idea of alternative compatible causes for the same phenomenon. If one ranks Smith's invisible hand together with 'gravitation' and the 'animal principle', it turns 
out that multiple causality, or better coexistence of observable causes and hidden causes, acting the former at a surface level and the letter at a deeper level, is constantly the focus of these different kinds of images ${ }^{26}$

\section{SMITHIAN ECONOMIC THEORY AND DEEP METAPHORS}

Three comments are in order at this stage. The first concerns Adam Smith's description of the economy. The main elements are labour and land, inherited from Petty, Cantillon, Steuart, and the Physiocrats. According to Smith's scheme, production amounts to extracting commodities from land, and each commodity is equivalent to a portion of land into which some amount of labour has been infused. Another notion is drawn from the Physiocrats, namely the idea of renascent wealth, or of wealth as something that may be the seed that will yield a crop, or more wealth. In Smith's construction, nothing is completely new: everything has been built by building blocks taken from the ruins of his predecessors buildings; but the meanings of these building blocks are twisted and blended up with each other in the course of the reconstruction process. The outcome is that, for example, productive labour is not only work spent in the production of agricultural produce, but also every kind of work spent in producing any kind of material goods, or all work that 'fixes and realizes itself in some particular subject or vendible commodity, which lasts for some time at least after that labour is past' (Smith [1776] 1976, II.iii.1, p. 330). In another language, labour-as-force is transformed into labour-as-energy, embodied into a portion of matter, and thus able to exert an attractive force on potential labour (or, 'labour force'). Or again, it is the production of material goods that gives revenue, which one may later choose to consume or invest. If material goods are used as capital goods, more labour may be mobilized during the subsequent productive cycle. Mixed metaphors were usual in the baroque age and then went out of fashion. Adam Smith's mixed metaphors are used at a deeper level by a writer who is far from baroque in his style qua writer; the readers of The Wealth of Nations quite often misunderstood such metaphors, or the whole allegorical texture of the work, in that they tended to note just the simplest mechanistic analogies and to take them literally.

The second comment concerns differences and similarities between transfer of notions from previous phases of economic discourse and from other disciplines. It may be appropriate to note that the transfer of notions takes place either in a vertical dimension - within the history of the same kind of discourse - or in an horizontal dimension - crossing the border between different kinds of discourse, say, from natural science to social science. In both cases the freshly described mechanism or the "imaginary machine" is not completely identical to the original one; it results from partial modification, always carrying some kind of extension. For example, when the Physiocrats' cyclical view of the economy is transformed into Smith's cyclical view, it labour value, not corn, that becomes the substance of self-renovating wealth; or also, when the Newtonian view of gravitation becomes Smith's view of gravitation of market prices, it is individuals as atoms (the 
etymology of both words is the same), not parts of matter that are put into motion by forces leading them to mutual equilibrium.

The third comment is that in The Wealth of Nations a unified domain of the economic was constituted through a process of metaphorical re-description, carried out primarily by means of a device that has always been a literary critic's bogey, namely mixed metaphor. In my reading, the examples of metaphor-statements I have reviewed are clues to deeper metaphorical re-descriptions. The national economy becomes for Adam Smith a whole, with its own 'laws' (i.e. societal laws, different from 'laws' in a literal sense, i.e. legal and moral laws), precisely in so far as it is described not in terms of individual human beings and physical goods, but in terms of the metamorphoses of a 'substance', exchange-value. In this way a world emerges that is analogous to the Newtonian physical world, with its own forces, action at a distance, mass and energy. This world may be conceived as an imaginary machine: the simple machine of 'gravitation' or the more complex machine of 'circulation'; but circulation is not only an analogon of the Copernican solar system: it is also, on a number of occasions, analogous to Harvey's human body, with blood circulation, and of the Physiocrats' 'real' economy, with its circulation of corn (and here the mixed metaphor celebrates its own apotheosis). Finally, the 'imaginary machine' of wealth may somehow reflect an (unknowable) unified world order like that conceived by the Stoics, with absolute causal necessity and a perennial cyclical movement. One may add that there is scarcely any room for the opposition of mechanicism and organicism, as commonly understood since Marshall's times. In fact, the life sciences went into a revolutionary phase in the second half of the eighteenth century. This accounts for presence of biological analogy in the economics of both Quesnay and Smith. But the raison d'être of the biological scientific revolution was precisely the Newtonian legacy that inspired also the various projects of Moral Newtonianism where Smith's oeuvre belongs ${ }^{27}$. The key idea of the new approach to the life sciences was the assumption of a dual structure also for biological phenomena, following the blueprint of Newton's opposition of 'phenomena' and 'principles'.

To sum up, a basic physical-moral analogy provides the framework for the Adam Smith's overall social theory, and not surprisingly for his theory of market mechanisms. Even the famous invisible hand passage depends on the basic physical-moral analogy and accordingly implies less than the received view believes, that is, it is just meant to join a teleological with a causal explanation. Smith has recourse to other analogies, fitting them, as far as possible, to the basic machine analogy. For example, a blend of Locke's and the Physiocrats' view yields a view of labour in terms of energy undergoing subsequent transformation. The circulation scheme expands the machine scheme, transforming it into some kind of self-expanding machine. A iatro-mechanical analogy is as pervasive as the physical-moral analogy in Adam Smith's thinking and provides the framework for his overall evolutionary theory of society and for those passages in The Wealth of Nations where he has recourse to a theory of the self-correcting power of society that helps amending market failures and mistaken policies $^{28}$. 


\section{SMITHIAN METAPHORS AFTER ADAM SMITH}

Let us ask one more question. If Adam Smith's metaphors are the mark of something deeper and more important than his literary style, did they leave any bequest to later economic thought? Let us see what happened to them when, at the turn of the century, The Wealth of Nations began to be quoted as the greatest authority in what was now believed to be the science of 'political economy'.

Let us start by reading the following passages from Ricardo's Principles:

Gold and silver are no doubt subject to <fluctuations> (Ricardo [1819] 1951, p.14)

the correct language would be to say, that corn and labour have remained <stationary>, and all other things have <risen> in value (Ib., p. 19)

a $<$ fall $>$ in their value and not a <rise> in the value of the things with which they are compared (Ib.)

labour, as being the <foundation> (Ib., p. 20)

I suggest that the words marked in the above quotes embody frozen metaphors; these seem to imply the assumption of a spatial dimension in which the economy is placed, a universe of forces like that of Newtonian physics, and the idea of value as a physical object. If we follow the story told through ch. 1 of the Principles, the value-as-a-substance mixed metaphor may be taken as a key to the chapter. The chapter's plot then becomes the following: value is a thing, a physical magnitude, consisting at once of Corn and of Labour, and this thing remains invariable through its transformations into various commodities ${ }^{29}$.

Let us consider now a few passages from Malthus's Principles:

the <laws> which regulate the <movements> of human society (Malthus [1820] 1989, p. 11)

Man [...] is the primary <source> of all demand (Ib., p. 83)

the separation of rents [...] is a <law> as invariable as the action of the <principle of gravity> (Ib., p. 123, fn. 17)

the natural restrictions upon the importation of foreign corn during the war [...] may have directed the capital of the country into a <channel> more advantageous than that it would otherwise have <flowed> (Ib., p. 328)

Here we have a set of statements embodying metaphors somewhat different from Ricardo's. Not unlike him, Malthus assumes the framework of Newtonian physics as a model, but, unlike him, the spatial/physical representation of the economy is subordinated to a higher-level representation based on a system of 'laws' or 'principles' that supervises the direction of the 'flows' and 'movements' through the 'channels' of the economy. 
These motives are combined with others, deriving from older strata of metaphorical redescription. One example is the following simile (applied to Laissez Faire):

The ablest <physicians> are the most sparing in the use of <medicine>, and the most inclined to trust to the healing $<$ power> of nature (Ib., p. 15).

The simile is a variation on Adam Smith's application of the older iatro-political metaphor to the economy. Another simile is an elaboration on an earth-as-a-machine metaphor. Malthus writes:

The earth has been sometimes compared to a <vast machine> [...] for the production of food and raw material; but, to make the resemblance more just $[\ldots]$ we should consider the soil as $[\ldots]$ a <great number of machines> [...] of very different original qualities and powers (Ib., p. 135).

I suggest that for Malthus and Ricardo the description of the economy in The Wealth of Nations had already become a starting-point, and Smith's metaphors were almost frozen metaphors. And yet, on the basis of such a shared vision, a number of differences emerge: there is a preference by each of them for certain nuances within this cluster of metaphors, or shifts in the barycentre of this cluster. Thus, the organic metaphor is constantly (albeit not exclusively) preferred by Malthus; one reason for this preference may be that it allowed for implications which responded to the need to take a multiplicity of factors (social, cultural, institutional) into account, which was in its turn prompted by his strategy and 'scientific style' ${ }^{30}$.

Besides, new metaphors (such as Crises, Growth, Land as the Outer Limit to the expanding wheel of the economy), while apparently describing a Smithian world as if it was the world out there (or a 'natural kind'), may be understood as something more than rhetorical stratagems employed in order to depict the facts in some preferred way, and also something more than heuristic devices. They may be understood as shifts in the below-the-water-line part of their precomprehension of the subject matter and of the categories through which that subject matter might be organized or, in Foucault's words, in the shared episteme.

A shift introduced in a metaphor is a part of a more general strategy: for example, talk of economic laws may have different implications: laws may be expressions of an immanent physico-moral order of the world, like the Physiocrats, or they may be 'superimposed' on the original motions of such entities via the unintended-results principle, like Adam Smith. In Malthus we find a preference for the expression 'cause' instead of law. Ricardo is fond of the expression 'law', albeit in his writings the term assumes a connotation opposite to that of the Physiocrats: an economic law for Ricardo is more similar to a mathematical law than to natural law.

The introduction of new metaphors into an already shaped metaphorical (re)description of the world, these have the consequence of modifying it. A good example is the appearance of the idea of crisis in economic thought: the word 'crisis' in a political (and then economic) sense, comes into use at about the time of the French Revolution. 'Crisis' - etymologically 'judgement' - comes from juridical, medical and theological jargon. The word started to be used in English in the last decade of the eighteenth century in order to describe 
the high risk of a sudden social change or a <revolution> (in its turn an astronomico-political metaphor). The first pamphlet by Malthus was entitled precisely The Crisis. In Malthus's political economy the permanent risk of under-consumption hints precisely at "the risk of an economic crisis, in present-day jargon, or of the beginning of one of those "intervals" of disturbances which use to show up between two "permanent states" in the economy. We already met 'cycles' in Adam Smith, where they were a legacy of the Stoical view of history. Yet, talk of 'crises', instead of 'cycles', conveys an image of historical trends as more precarious and unstable. This makes room for a prudent intervention by the politician, if not in the role of Adam Smith's 'man of System' trying to impart an artificial order to society, at least in that of a helmsman who skips the opposite shoals of under-consumption or of too sudden rises in public expenditure.

A similar reconstruction might be made for other root-metaphors used in economic discourse at Malthus's and Ricardo's time. One is that of 'growth' of food and population, central to Malthus's Essay on the Principle of Population; it brings into the picture one biological metaphor that was still absent in Smith, waiting to be explored by later evolutionary approaches in economics, from Marshall to social Darwinism. Another is the metaphor of Land as the Limit. At the time of the multiple discovery of the law of rent by Malthus and others, the Land, understood as a series of increasingly less efficient machines for the production of food, is yet another metaphor added to Adam Smith's vision. The new metaphor thus added modifies and expands one of the basic metaphors in his work, equilibrium.

Here, with the principle of population and rent theory, we face a feedback loop, where the addition of one more unit of population and/or food, or the tillage of one more unit of land retro-act upon the whole system. Even if the kind of analogy is basically the same as in Smith's gravitation of prices, its role is quite different: in Smith the feedback acts within the economic system, whose development is basically governed by another logic; in Malthus the feedback governs the external boundaries of the economic system, and accordingly its chances of growth or stagnation.

\section{DEEP METAPHORS}

If metaphors are not just a marginal feature of Adam Smith's discourse, what use might we make of such metaphors? We may, with Braithwaite, Boyd and other philosophers of science from the Fifties and Sixties, look for their heuristic function, if any, and then go on with the more serious pursuit of studying how scientific terms have an empirical content, or refer, or <cut the world> at its proper <junctures>, or we may, with McCloskey, examine how metaphor works as one more way (besides 'story', 'logic', and 'fact) of introducing order, of unifying appearances, and thereby, hopefully, convincing an audience. But we may also try to single out deeper basic metaphors behind individual metaphorical statements. These deep metaphors mould ways of 'seeing' one domain (the economic) in terms of some other domain. And it is this Wittgensteinean process of 'seeing as' what lies at the root of any new conceptual mapping. ${ }^{31}$ 
For many economists, one of McCloskey's astonishing discoveries was that also economists use metaphors. And yet, despite their astonishment, the standard response has been: 'yes, thank you, and then?' In fact, this is the way 'orthodox' philosophy of science used to deal with the topic: metaphors-models are used by scientists as by anybody else, but they are useful at most in some preliminary phase - be it the context of discovery, like Braithwaite, or the introduction of new scientific terms, like Boyd - after which they are substituted by literal meanings. Metaphors may thus be present, and even ubiquitous, in science, but they have no permanent cognitive value. One reason for this defensive reaction is that metaphor is generally equated with vagueness, and science with precision. ${ }^{32}$ McCloskey on the contrary insisted that metaphor is ubiquitous in economic discourse; that model building, the most mathematical part of the economist's job, which gives to economics the aura of a 'hard' science, is instead the point where it comes closer to poetry; that metaphor is always a 'way of doing things with words', and distinguishing its poetical and its scientific use means missing its specific function ${ }^{33}$.

McCloskey is right in giving metaphor as full citizenship in science as in poetry and in stressing the creative function of metaphor in science. What is wrong with such an account is, first, an equation of science with fiction as different means of producing persuasion. ${ }^{34}$ Secondly, a belief that the fact that economists make things with words pertains primarily to the perlocutionary aspect of language and accordingly that the economist's use of metaphor is almost arbitrary, being one among other means for producing persuasion and, as I will argue in the next paragraph a fixation with the literary style of the economists' writings, overlooking what really matters, i.e. their 'scientific style'. ${ }^{35}$

Things are even worse with Brown's discourse: if the reconstruction carried out in the present paper makes sense, the claim that metaphors are ubiquitous is fine; but this is not tantamount to saying that we may give any meaning we like to texts reading metaphors freely. The success of Brown's attempt depends on the viability of the conclusion that 'if, following the meaning of vision metaphors in TMS, vision refers to moral judgement, then the metaphor of the invisible hand signals that the invisible hand, being sightless and out of sight, is beyond the realm of moral discourse' ${ }^{36}$ But 'invisibility' of hands, chains, wheels, and hidden or imaginary machines of any sort depends on a distinction of a phenomenal and a deeper level of causal connections, not on the visibility of behaviour to a judge. And the ascription of the above meaning to Smith's 'invisibility' depends on the reconstruction of a context of received concepts and theories. The Wealth of Nations belongs to this context in force of objective reasons, not of any decision by the author of this paper. In other words, the reading of Adam Smith's metaphors need not be metaphorical, no less than theories on the chemical composition of sugar need to be sweet.

To sum up: economists are not free to choose any metaphor they like, for they 'are subject to constitutive metaphors' and these 'are not picked up and discarded like heuristic metaphors or mere preferences'. ${ }^{37}$ Mirowski's historical epistemology has granted metaphor a role much more basic than McCloskey's, looking beyond surface metaphorical expressions, and identifying deep basic metaphors, such as the physico-moral parallel underlying the modern world-view which also moulded economic science. This overlaps fairly well 
with what I suggest here insofar as it means taking developments in post-empiricist philosophy of science on scientific metaphor seriously. ${ }^{38}$

Let me add some more words on these developments. The claim that science has recourse to anthropomorphic metaphors had been first advanced by philosophers as different as Nietzsche and Peirce have been. The new rhetoricians Richards and Burke, the aesthetician Stephen Pepper and, more recently, the linguist George Lakoff have reformulated the same claim. The Nietzsche-Peirce thesis contends that no genre of discourse is immune from tropes, scientific discourse included, and metaphor is the master trope of science, the basic tool for organizing and exploring the unknown, and thus - against Aristotle - it is more basic to science than to poetry. After the war waged by Galileo, the Royal Society, and Newton against metaphor and rhetoric in the name of 'plain discourse' and 'facts', and after the Romantic rescue of metaphor in the name of a rebellion against the Enlightenment, metaphor was believed by both camps to be the mark of poetry, religion, and myth, as opposed to the field of science where precision and literality rule. Still a few decades ago, philosophers of science, ranging from logical empiricists such as Hempel and Braithwaite to metaphysical realists such as Boyd, were prepared to condone models and analogies either as tools for a scientific heuristic or as means of introducing new scientific terminology. Mary Hesse, Donald Schön, Peter Achinstein, Marx Wartofsky, Thomas Kuhn, and Gilles-Gaston Granger argued for indispensable and non-provisional role for metaphor in scientific theory. A radicalized version of this view was formulated by George Lakoff, according to which metaphors are constitutive of languages and provide the conceptual underpinning of the 'life-world'. To study the role of metaphor in science, then, is tantamount to analysing the structure and interplay of mappings of different fields of phenomena onto each other. ${ }^{39}$

\section{SCIENTIFIC 'STYLE'}

What Adam Smith did in The Wealth of Nations was not a mere exercise in persuasion; neither was it the application of an analytic toolbox to economic phenomena. His achievement was shaped by a handful of metaphors that was productive of fresh ways of seeing as. The partially sceptical epistemology he had learned from his friend David Hume helped in a way, namely, in making his mind soft enough. He knew too well that the economy could not be really made of motions and attractions, dams and rivers, vessels and fluids; for he knew too well that even Newton, the intellectual hero of his century, had not lifted the veil which hides the concealed mechanism of Nature. The legacy of Hume's moderate scepticism left him free from dogmas. But he did not limit himself to describing the phenomena. Indeed, he looked at the phenomena though his preferred metaphors and made his successors see them in a different way. As I have illustrated, the phenomena were no more the same for his successors Malthus and Ricardo. The reason for that is that the cognitive function of metaphors goes beyond the context of discovery; instead, metaphors did shape, or re-describe, or carve off the very field of phenomena that was afterwards be taken to be 'the' economy out there. 
A role for metaphorical re-description in producing the very empirical basis of economic theory is no argument against truth and theoretical progress. Instead, it was a blissful choice of metaphors, different from his predecessors', that helped Adam Smith in widening the scope of economic explanation, in imagining counter-intuitive connections among traditionally separated fields of phenomena, in shaping new hypotheses to be tested, while nothing in the 'observed' phenomena would have suggested such hypotheses. The combination was the result of a number of factors: historical contingencies, fashion, esthetical standards, and the scientific style of his age as well as his own individual scientific style.

Let me add - in order to stress the difference between the approach that has been proposed here and those of McCloskey and Brown - that a scientific style is something else than the literary style of a scientist's writings; instead, it is 'style' in the same sense in which we talk of baroque or neo-classical style for painting and architecture, that is, a complex of ways of expression bound together by elective affinities or family resemblance and yet able to confer some unity to artistic or literary products of one age or author and useful for decoding the 'language' of the same age or author. Applied to scientific theories, a style may be the complex set of factors that account for preference for certain ways of concept building and theorizing, that is, for something that comes virtually before writing. Understood in the latter sense, this category may prove useful for the history of economic thought, and it may help in exploring dimensions of the history of economic thought that may go beyond pure methodology, if this is understood in a stricter sense, but are also wider than the study of the literary style of economic texts. 


\section{NOTES}

*I wish to thank Marcelo Dascal for suggestions on metaphor and pragmatics, Gideon Freudenthal for suggestions on Newtonian science, and Gianni Vaggi for his comments at the Graz Conference that forced me to dispel some of the mist hovering around my claims; the remaining is my own.

${ }^{1}$ I develop a few suggestions on the role of metaphors in The Wealth of Nations presented in Cremaschi 1984, pp. 147148 and 187-189; essentially the same suggestions were made in Fiori 1996; Mirowski reached independently similar conclusions (1989, pp. 163-171).

${ }^{2}$ On the notion of 'scientific style' and its relevance to the history of economic thought, see Cremaschi and Dascal 1999.

${ }^{3}$ J. Schumpeter [1954] 1994, p. 182.

${ }^{4}$ See Smith [1795a] 1980, II.8-9, p. 42; for commentaries see Cremaschi 1981; Cremaschi 1984, ch. 1; Cremaschi 1989, pp. 85-87.

${ }^{5}$ That is, technology is to Smith what geometry and politics were to Hobbes and history to Vico: see Cremaschi 1989, pp. 85-87.

${ }^{6}$ The role of analogy in Adam Smith's epistemology is discussed in some detail in Cremaschi 1981 and 1984 , ch. 1.

${ }^{7}$ See the sensible comments in Brown 1994, pp. 15-17; I disagree with further implications drawn by Brown in the following.

${ }^{8}$ Brown 1994, p. 24.

${ }^{9}$ See Brown 1994 p. 19 fn. for the opposite view.

${ }^{10}$ This is why scientific discourse, far from being monologic, is essentially dialogical or controversial. This is the reason why Brown's way of reviving das Adam Smith Problem, namely contrasting a dialogical character of The Theory of Moral Sentiments with a monological character of The Wealth of Nations is off the track from the very beginning.

${ }^{11}$ This is one important mark of the Newtonian methodological legacy in Adam Smith's economic theory: see Cremaschi 1984, pp. 138-151; 1992, pp. 59-61.

12 'Theodicy', after the title of a notorious work by Leibniz, indicates the solution of the problem of the existence of evil in a world supposedly created by a benevolent God.

${ }^{13}$ Exceptions are Foley 1976; Worland 1976; Mirowski 1989. Foley is a useful source, but his overall interpretation od Adam Smith's system of ideas is quite old fashioned.

${ }^{14}$ Here and in following quotes, I mark words whose metaphorical valence I intend to point out.

${ }^{15}$ For a similar point concerning the division of labour instead of the allocation of capital, see Smith [1776] 1976, I.ii.1, p. 25 .

${ }^{16}$ Curiously enough, Quesnay had used himself a biological metaphor (the national economy is a tree; industry and commerce are the branches; agriculture is the land that feeds the tree) in order to make himself an anti-artificialist claim: 'il faut donc cultiver le pied de l'arbre, et ne pas borner nos soins à gouverner les branches; laissons-les s'arranger et s'étendre en liberté, mais ne négligeons pas la terre qui fournit les sucs nécessaires a leur végétation et à leur accroissement' (Quesnay 1758, p. 473).

${ }^{17}$ For discussion of this passage see Macfie 1971.

${ }^{18}$ The claim of a coexistence of two different voices in Smith's economic work and in his moral work has been put forth in Brown 1994; for a criticism see Cremaschi 1997; the relevant point here is that the function of metaphors is 
both persuasive and cognitive in both works, and this may cast some doubts on the idea that the discourse is cast in one work in a 'dialogical' mould while in the other it is carried out within a 'didactical' framework.

${ }^{19}$ See R. Brown 1984, chs. 2 and 3.

${ }^{20}$ On the pamphleteers see R. Brown 1984, ch.1; on the Physiocrats as well as on ancient sources see Lowry 1974.

${ }^{21}$ The image of the Hand of God has a long history before Priestley. It was a way of talking of God's action, derived from a way of representing God's action by painting a hand without a body, complying with the ban on images from the Bible. This way of representing God was usual in Jewish art and appeared occasionally also in Christian art. On the idea of the Hand of God see also Macfie 1971.

${ }^{22}$ See Quesnay 1758 and 1757.

${ }^{23}$ See Quesnay 1758; Mercier de la Rivière 1767, p. 206.

${ }^{24}$ see Mayr 1986.

${ }^{25}$ As suggested in Worland 1976; a discussion of Newtonian items in the theoretical structure of The Wealth of Nations is in Cremaschi 1992, pp. 61-64 and in Freudenthal, 1982.

${ }^{26}$ See Cremaschi 1984, pp. 148-151; cf Fiori 1996.

${ }^{27}$ See Cremaschi 1992; 1981; Freudenthal, 1982.

${ }^{28}$ See Jensen 1976; Cremaschi 1984, ch.4.

${ }^{29}$ This is the suggestion made in Mirowski 1989, pp. 163-171.

${ }^{30}$ For more detailed discussion of this point see Cremaschi and Dascal 1998.

${ }^{31}$ For more detailed discussion see Cremaschi 1987; 1988a; 1988b; 1997.

32 See Cremaschi 1988a; 1988b; Klamer and Leonard 1994, pp. 20-21.

${ }^{33}$ See McCloskey 1985; 1990; 1994; cf. Cremaschi 1996.

${ }^{34}$ Instead, science and poetry or novel are not different for the use they make of metaphor, but they are nonetheless different in other respects, and these respects relate to practice, not to language.

${ }^{35}$ Instead economic metaphors are both for cognitive and non-arbitrary, and but their illocutionary aspect - as contrasted with the perlocutionary - is what matters.

${ }^{36}$ Brown 1994, p. 26.

${ }^{37}$ Klamer and Leonard 1994, p. 43; see also Lakoff 1987; Henderson [1982] 1993; Cremaschi 1988 b.

${ }^{38}$ Mirowski 1989; 1994.

${ }^{39}$ See Cremaschi 1987; 1988a; 1988b; cf. Gross 1990; Backhouse, Dudley-Evans and Henderson (1993). 


\section{REFERENCES}

Backhouse, Roger E. (ed.) (1993), New Directions in Economic Methodology. London and New York: Routledge.

Backhouse, Roger E., Terence Dudley-Evans, and William Henderson (1993), 'Exploring the Language and Rhetoric of Economics', in Henderson, et al. (1993), pp. 1-22.

Brown, Robert (1984), The Nature of Social Laws. Machiavelli to Mill. Cambridge and New York: Cambridge University Press.

Brown, Vivienne (1994), Adam Smith's Discourse. Canonicity, Commerce and Conscience, London and New York: Routledge.

Cantillon, Richard (1755), ed. by T. Tsuda (1979), Essai sur la nature su commerce en général, Tokyo: Kinokuniya Book Store.

Cheyne, George (1725), Essay on Health and Long Life, fourth edition, London: Strahan.

Cotes, Roger (1712) 'Cotes to Newton' (Letter n. 985: 18 March 1712), in H.W. Turnbull and J.F. Scott (eds) The Correspondence of Isaac Newton, London: Cambridge University Press, 1959-1977, 11 vols., vol. v.

Cremaschi, Sergio (1981), 'Adam Smith, Newtonianism and Political Economy', Manuscrito, 5, (1), 117 134.

Cremaschi, Sergio (1984), Il sistema della ricchezza. Economia politica e problema del metodo in Adam Smith, Milano: Angeli.

Cremaschi, Sergio (1987), 'Granger and Science as Network of Models', Manuscrito 11 (2), 11-136.

Cremaschi, Sergio (1988a), 'Metafore, modelli, linguaggio scientifico: il dibattito postempirista', in V. Melchiorre (ed.), Simbolo e conoscenza, Milano: Vita e Pensiero, pp. 31-102.

Cremaschi, Sergio (1988b), 'Remarks on Scientific Metaphors', in M.L. Dalla Chiara and M.C. Galavotti (eds), Temi e prospettive della Logica e Filosofia della Scienza contemporanee, 2 vols., Bologna: CLUEB, vol. II, pp. 114-116.

Cremaschi, Sergio (1989), 'Adam Smith. Sceptical Newtonianism, Disenchanted Republicanism, and the Birth of Social Science', in M. Dascal and O. Gruengard (eds), Knowledge and Politics: Case Studies on the Relationship between Epistemology and Political Philosophy, Boulder, US and London: Westview Press, 1989, pp. 83-110.

Cremaschi, Sergio (1992), 'L'illuminismo scozzese e il newtonianismo morale', in M. Geuna and M.L. Pesante (eds) (1992), Interessi, passioni, convenzioni. Discussioni settecentesche su virtù e civiltà, Milano: Angeli, pp. 41-76.

Cremaschi, Sergio (1996), 'Review of D. McCloskey, Knowledge and Persuasion in Economics', Pragmatics and Cognition. 4 (2), 425-429.

Cremaschi, Sergio (1997), 'Review of V. Brown, Adam Smith's Discourse', Journal of Economic Methodology, 3 (1), 174-176.

Cremaschi, Sergio and Marcelo Dascal (1998), 'Malthus and Ricardo: Two Styles for Economic Theory', 
Science in Context 11 (2), 229-254.

Fiori, Stefano (1996), 'Order, Metaphors, and Equilibrium in Adam Smith's Thought'. History of Economic Ideas, 4 (1-2), 175-204.

Foley, Vernon (1976), The Social Physics of Adam Smith, West Lafayette, US: Purdue University Press.

Freudenthal, Gideon (1982), Atom und Individuum im Zeitalter Newtons. Zur Genese der mechanistischen Natur- und Sozialphilosophie, Frankfurt a.M.: Suhrkamp; translated as (1986) Atom and Individual in the Age of Newton, Dordrecht: Reidel.

Gross, Alan G. (1990) The Rhetoric of Science, Cambridge, US: Harvard University Press.

Henderson, William (1982) 'Metaphor and Economics', in Backhouse (1993), 343-367.

Henderson, William, Terence Dudley-Evans, Roger Backhouse (eds) (1993), Economics and Language, London and New York: Routledge.

Hume, David (1752a), 'Of the Balance of Trade', reprinted in T.H. Green and T.H. Grose (eds) (1964), Essays Moral, Political, and Literary, Aalen: Scientia Verlag, vol. I, pp. 330-345.

Hume, David (1752b), 'Of Money', reprinted in T.H. Green and T.H. Grose (eds) (1964), Essays Moral, Political, and Literary, Aalen: Scientia Verlag, vol. I, pp. 309-320.

Jensen, Hans E. (1976), 'Sources and Contours of Adam Smith's Conceptualized Reality in The Wealth of Nations', Review of Social Economics, 34 (3), 259-274.

Klamer, Arjo, Theodor C. Leonard (1994), 'So What's an Economic Metaphor?', in Ph. Mirowski (1994), pp. 20-54.

Locke, John (1690), 'The Second Treatise of Government', reprinted in P. Laslett (ed.) (1988), Two Treatises of Government, Cambridge and New York: Cambridge University Press.

Lowry, S. Todd (1974), 'The Archaeology of the Circulation Concept in Economic Theory'. Journal of the History of Ideas, 35 (3), 429-444.

Lakoff, George (1987), Women, Fire, and Dangerous Things. What Categories Reveal about the Mind, Chicago: University of Chicago Press.

Macfie, Alec L. (1971), 'The Invisible Hand of Jupiter', Journal of the History of Ideas, 32 (4), 595-599.

Malthus, Thomas Robert (1820, 1836), ed. by J. Pullen (1989), Principles of Political Economy, Cambridge: Cambridge University Press.

Mayr, Otto (1986), Authority, Liberty and Automatic Machinery in Early Modern Europe, Baltimore: John Hopkins University Press.

McCloskey, Donald N. ([1985] 1998), The Rhetoric of Economics, Madison, US and London, UK: University of Wisconsin Press.

McCloskey, Donald N. (1990), If You're So Smart: The Narrative of Economic Expertise, Chicago: University of Chicago Press.

McCloskey, Donald N. (1994), Knowledge and Persuasion in Economics, Cambridge and New York: Cambridge University Press, 1994.

Mercier de la Rivière, Pierre-Paul (1767). L'ordre naturel et essentiel des sociétés politiques. Londres. 
Mirowski, Philip (1989), More Heat than Light: Economics as Social Physics, Physics as Nature's Economics, Cambridge and New York: Cambridge University Press.

Mirowski, Philip (ed.) (1994), Natural Images in Economic Thought, Cambridge and New York: Cambridge University Press.

Priestley, Joseph (1788). Lectures on History and General Policy, reprinted in J.T. Rutt (ed.) (1972), Theological and Miscellaneous Works of Joseph Priestley, vol. XXIV, New York: Kraus Reprint.

Quesnay, François (1757), 'Grains', reprinted in (1958), François Quesnay et la Physiocratie. Paris: Institut National d'Études Démographiques, vol. II, pp. 459-510.

Quesnay, François (1758), 'Tableau Economique', reprinted in M. Kuczynski and R.L. Meek (eds) (1972), Quesnay's Tableau économique, London: Macmillan, and New York: Kelly.

Ricardo, David (1817), On the Principles of Political Economy and Taxation, reprinted in P. Sraffa (ed.) (1951), The Works and correspondence of David Ricardo, vol. I, Cambridge and New York: Cambridge University Press.

Schumpeter, Joseph A. ([1954] 1994), History of Economic Analysis, London: Routledge and New York: Oxford University Press.

Smith, Adam (1759), The Theory of Moral Sentiments, reprinted in D.D. Raphael and A.L. Macfie (eds) (1976), Glasgow Edition of the Works and Correspondence of Adam Smith, vol. I, Oxford: Oxford University Press.

Smith, Adam (1776), An Inquiry into the Nature and Causes of The Wealth of Nations, reprinted in R.H. Campbell, A.S. Skinner, and W.B. Todd (eds) (1976), Glasgow Edition of the Works and Correspondence of Adam Smith, vol. II, Oxford: Oxford University Press.

Smith, Adam (1795a), The Principles which lead and direct Philosophical Enquiries: illustrated by the history of Astronomy, reprinted in W.P.D. Wightman, J.C. Bryce, and I.S. Ross (eds) (1980), Glasgow Edition of the Works and Correspondence of Adam Smith, vol. III, Oxford: Oxford University Press. 